\title{
POWER DIMENSIONS AND CHINESE STRATEGY FOR OIL ACQUISITION AT THE DAWN OF THE 21ST CENTURY: AN ANALYSIS OF THE CASES OF KAZAKHSTAN, ANGOLA AND VENEZUELA ${ }^{1}$
}

Niels Sondergaard ${ }^{2}$

\begin{abstract}
The objective within the study is to evaluate the modalities of the Chinese power projection, within the country's strategy to gain access to develop crude reserves in developing countries. Liberal Institutionalist perspectives upon the concept of power are applied as the central theoretical framework for analysing the Chinese performance in the cases of energy cooperation with Kazakhstan, Angola and Venezuela. A strong reliance upon tangible power resources as material inducement is identified as an essential part of the Chinese energy strategy. This also serves as a necessary pre-condition for the establishment of channels through which intangible power resources can be applied.
\end{abstract}

Key Words: China; Natural recourses; Energy; Oil; Power.

\section{Resumo}

O objetivo do estudo é avaliar as modalidades da projeção chinesa de poder dentro da estratégia deste país para obter acesso para desenvolver reservas de petróleo em países em desenvolvimento. Perspectivas Liberais Institucionais sobre o conceito de poder são aplicadas como arcabouço teórico central para analisar a atuação Chinesa nos casos de cooperação na área de energia com Cazaquistão, Angola e Venezuela. Uma forte dependência de recursos de poder de natureza tangível, como indução material, é identificada como parte central da estratégia energética da China. Isto também serve como uma pré-condição necessária ao estabelecimento de canais por meio dos quais recursos de poder de natureza intangível possam ser aplicados.

Palavras Chaves: China; Recursos naturais; Energia; Petróleo; Poder.

\section{Resumen}

El objetivo del estudio es evaluar las modalidades de la proyección de poder chino, dentro de la estrategia del país para conseguir desarrollar recursos de petróleo en países en vía de desarrollo. Perspectivas Liberales Institucionales sobre el concepto de poder son aplicadas como marco teórico central para analizar la actuación china en los casos de cooperación energética con Kazakstán, Angola y Venezuela. Una fuerte dependencia de recursos de poder de naturaleza tangible, como medio de inducción material, es identificada como parte esencial de la estrategia china. Esto también sirve como pre-condición para el establecimiento de canales a través de los cuales recursos de poder intangibles puedan ser aplicados.

Palabras-clave: China; Recursos naturales; Energia; Petroleo; Poder.

\section{INTRODUCTION}

The objective within the present study is to evaluate the modalities of the Chinese power projection, as part of the country's strategy to gain access to develop crude reserves in developing countries. Thereby, the aim of the analysis is to understand how the application power recourses becomes evident in particular Chinese interactions with crude producers.

\footnotetext{
${ }^{1}$ DOI deste artigo: $10.5380 /$ recp.v6i1.39783.

${ }^{2}$ Doutorando no Instituto de Relações Internacionais (UNB), bolsista Capes. E-mail: niels@soendergard.dk
} 
The article departs from the hypothesis that the exercise of power, as part of the Chinese recourse acquisition strategy, is a multifaceted process, through which a range of interrelated power recourses become activated. The liberal institutionalist perspective serves as the central theoretical framework for the study. The notion of power is treated through conceptualizations by Joseph Nye (1990; 2004; 2011) combined with Zhimin Chen and Lulu Chang's (2013) further elaborations of this. The article is structured as a case study, within which recent Chinese relations with Kazakhstan, Angola and Venezuela are reviewed in order to be able to classify the Chinese power projection with regards to the different conceptual dimensions, to which it relates. A parallel objective is to assess the consistency between 1) the fundamental Chinese foreign policy goals, 2) the country's strategy regarding energy related cooperation and obtainment, as well as 3) the specific tactics applied in the source countries examined. A strong reliance upon tangible power resources for material inducement is identified, as an essential part of the Chinese energy strategy. This however, should not be understood as being in contrast to or as incompatible with measures of soft power inducement, but rather as a necessary pre-condition for the establishment of channels through which intangible power resources can - and have - been applied.

\section{POWER AND ITS EVOLVING DIMENSIONS}

The Chinese strategy for overseas resource acquisition and the modality of power which the country employs in line with this must be evaluated, in relation to the constantly changing structural opportunities for the exercise of power, within the present global scenario. As a leading liberal-institutional scholar, Joseph Nye has elaborated the evolving nature of power, in a series of productions since the end of the cold war. In his work from 1990, Bound to Lead, Joseph Nye emphasizes how power has become less coercive, less fungible and less tangible (NYE, 1990). This is due to an increasing complexity of international politics, which means that a strong overall leverage which one country enjoys in relation to another will not necessarily translate into the former being able to shape the outcome of an issue, within which the later also has a stake (NYE 1990, p.175). Increasing interdependence is also a factor which limits the options for successful coercive power application, thus, in many instances rendering measures based upon attraction, as the most efficient strategy (Ibid, pp.190-191). In his later work from 2004, Soft power: the Means to Success in World Politics, Joseph Nye operates with the concept of power divided into hard power and soft power; whereas hard power rests on the material capability to command or induce and is associated with tangible resources, soft power is constituted by intangible 
resources such as co-option and agenda setting (NYE 2004, p.7). Nye (2011) similarly underlines that hard power resources contain both the potential for coercion as well as attraction, depending upon their mode of application (NYE 2011, p.16). Soft power, on the other hand is defined as "the ability to affect others through the co-optive means of framing the agenda, persuading, and eliciting positive attraction in order to obtain preferred outcomes." (Ibid, pp.20-21). Different power resources are also related to certain types of goals. Soft power is particularly useful for shaping an environment according to preferred norms of interaction, whereas hard power often proves to be more effective in obtaining more specific and tangible objectives, - a category within which Nye counts the acquisition of natural resources (Ibid p.16). The notion of smart power constitutes one of Nye's most recent elaborations of the general concept. With this, Nye questions the idea that the possession of power recourses necessarily will lead the wielder to obtain his/her preferred outcomes in a ratio proportional to the amount of power applied. The process of power application by itself constitutes a vital intermediate link, which is analyzed with particular regards to essential questions such as the preferred outcome, recourses available in the given context, the positions of objects sought influenced, which type of power is more likely to be useful, and finally, with what probability? (Ibid, pp.208-209). Nye thereby "opens" the concept of power to become more dependent upon relational and contextual complexities.

Adapting Joseph Nye's conceptualizations of the differentiated nature of power into an operational framework, used to analyze the contemporary Chinese power projection within the international system, Chen and Chang (2013) elaborate this through a model containing the dimensions of attraction versus coercion, referring to the mode of power application, and material versus non-material, referring to the nature of power resources (CHEN \& CHANG 2013, p.10). Attraction can thereby rely on both material resources, - soft hardpower - as well as non-material resources - soft soft-power. The same way, coercion can both take place through non-material means, as well as by the application of material resources, or rather, through hard soft-power or hard hard-power, as illustrated in figure 1 below: 


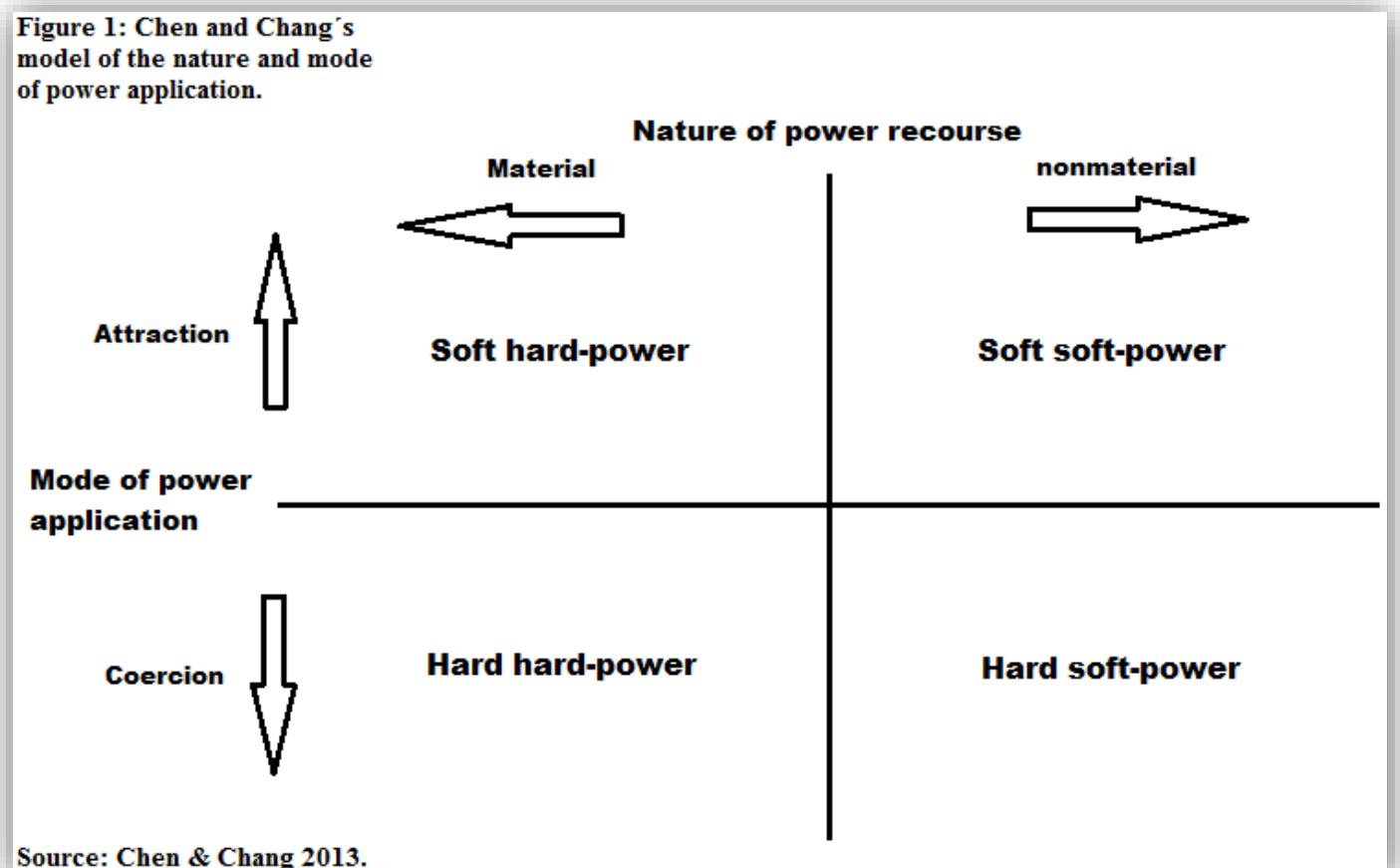

Source: Chen \& Chang 2013.

In the case of China, the authors nevertheless underline that the country by and large tends to rely on attraction rather than coercion, ascribing this circumstance to the country's tradition of 'peaceful diplomacy' (Ibid p.18). Regarding Chinese resource acquisition abroad, which mostly takes place far from its military sphere of influence, it is also logical that an analysis of the modalities of the country's power application related to this purpose, must focus upon measures of attraction, as coercion must be presumed to be an inefficient strategy, under the present conditions.

From the constructivist perspective, the liberal-institutional perception of power has been criticized for "falling into the realist trap" of basically accepting the materialist nature of power, while still reserving some space for a "relative autonomous" essence of ideational power. Alexander Wendt stresses the importance of turning attention towards the discursive conditions shaping the perceptions related to, - and thereby the essential nature of the exercise of - power. Emphasis is thereby laid upon how the differing contexts of meaning shape the causal outcome of materialist explanations (WENDT 1999, pp. 135-137). In line with this argument, the intention in the following analysis is thereby also to assess how the "perceptual reception" of the Chinese application of power resources is bound to lead to different outcomes depending upon the normative and ideational context, within which they are effectuated.

Another question relates to whether it is indeed possible to characterize the great variety of different interactions between both private and public Chinese entities on the one 
hand, and those of a raw material exporting abundant countries on the other, as part of the same 'resource strategy'. David Lampton underlines that the Chinese foreign policy-making has become increasingly pluralized and characterized by the presence of a great multiplicity of actors and institutions (LAMPTON 2001, p.4). This has also been paralleled by an emerging Chinese perception of the necessity of cultivating power in a broad range of different spheres (SHAMBAUGH 2013, p.6) which also complicates the task of clearly illustrating that efforts made within one apparently autonomous issue area, are at least partially undertaken in order to promote specific objectives related to another issue. Economy and Michael also stress the fact that there is a great internal competition between Chinese State Owned Enterprises (SOEs), which often act according to their own objectives (ECONOMY \& MICHAEL 2014, p.51). Yet the authors still indicate a correlation between Chinese aid and infrastructure provision, and a subsequent facilitation of access to resources. (Ibid, p.55). McCarthy (2013) also finds that even though Chinese SOEs adhere to certain centrally mandated 'guiding principles', they often make decisions based upon purely commercial rationale, and should not merely be perceived as policy instruments (MCCARTHY 2013, p.279).

Some relevant circumstances related to evaluating the connection between Chinese power projection and foreign energy acquisition objectives must be considered in the specific national context, within which it occurs. These are primarily concerned with 1) making the case that a multi-faceted power projection is at least in some degree related to the specific goal of accessing energy resources, and 2) distinguishing potentially "mercantilistic" aspects of Chinese energy companies and related entities behavior concerned with national energy security concerns, from 'normal' market oriented behavior. The cases of Kazakhstan, Angola and Venezuela, which are revised in the course of the article, have been selected according to the denominator of all being countries in relation to which energy interests are central within the Chinese foreign policy planning. Consequently, a certain degree of presence of energy related concerns within a multifaceted power projection strategy, is presumed to be evident in the instances of interactions examined within Chinese engagement with energy providers. In instances when the application of varying power resources appear to significantly and persistently foment Chinese SOE's access to energy sources, the strength and particular nature of this relationship can then be further elaborated, yet, without assuming a necessary "one-to-one" correlation. 
Finally, country cases from different geographical contexts have been selected, due to the intention of identifying consistent features of the Chinese policies for energy foreign acquisition, independent of the influences of any specific regional geopolitical situation.

\section{OIL STRATEGY WITHIN GENERAL FOREIGN POLICY GOALS}

Since the end of the cold war, China has been adhering to certain fundamental policy prescriptions defining the country's international engagement. In the late 1980ies the Chinese leader, Deng Xiaoping formulated the Tao Guang Yang Hui principle which refers to a policy of a very modest exposure of capabilities and keeping a low profile, as a central guideline for the Chinese international engagement (ZHAO 2013, p.103). The notion of Yu Guoji Jiegui which can be characterized as the aspiration of 'linking up to the international track' complemented these policies through the ambition of abiding to common norms of interaction and cooperation within the international society (XIAOYU 2012, p.355). An essential objective within this foreign policy orientation was to stride towards an international insertion, which would provide the necessary conditions for national development (SHAMBAUGH 2013, p.7; SUTTER 2012, p.12). Since the mid 1980íes, a new strong emphasis was assigned to Jingii Waijiao - economic diplomacy - within Chinese foreign affairs (HAMRIN 1998, p.89). In a speech in 1999, then Premier Minister Zhu Rongji established Zou Chuau - going out - as a prescriptive concept, referring to the need for resource entities and oil companies to create a solid international strategy for the overseas supply of such vital inputs for the growing Chinese economy (ECONOMY \& MICHAEL 2014, p.49). During the Jiang Zemin era, this also resulted in the Chinese state becoming increasingly involved in providing conditions which would spur such international engagement, through tax breaks, cheap credits and low interest funding (Ibid).

As has often been indicated by China specialists and pundits, the issue of resource scarcity poses a major challenge for the Chinese economy (SUTTER 2012, p.74). Markets which are characterized by steadily dwindling reserves and a rapidly increasing demand, such as the global oil trade, are very prone to a certain degree of zero-sum competition, which highlights the potential for conflict. This poses the question as to whether the ambition of a discrete low-profile engagement within these by China is indeed possible, and whether the country's means to obtain energy resources are fundamentally distinct from those applied by established players. A Chinese whitepaper on Africa from 2013 stresses the complementarity between China's need for resources and many African countries' need for investment and infrastructure provision. The overseas investment by Chinese enterprises is 
encouraged and their role in the construction of infrastructure is similarly underlined, yet, along with the importance of this taking place in accordance with international practice and the rules of the market economy'. Furthermore, the whitepaper also stresses that the new type of strategic Sino-African relationship also builds upon cultural and educational foundations, such as student exchange and joint research initiatives (CHINA GOV. 2013).

Another whitepaper on energy from 2007 stresses the importance of 'common development of energy around the world' as well as making 'positive contributions to worlds energy security and stability' (CHINA GOV. 2007). The whitepaper furthermore dedicates a section to 'Improving external cooperation in the exploration and development of oil and gas resources.' Hereby, the importance of product-sharing contracts and joint exploration and development, together with foreign companies, as well as their contractual security, is underlined. Interestingly, the Chinese government does affirm its ambition of depending less upon spot markets, through the encouragement of long-term supply contracts and the diversification of trading channels (Ibid). Robert Sutter criticizes this strategy and underlines that it expresses a lack of commitment to regulating scarcity on oil markets through institutional engagement, as well as a narrow focus upon Chinese energy security. Sutter furthermore underline that the high premium which China often pays for its oil wields a negative effect upon global prizes, as seen through a net-importer's perspective, such as the US (SUTTER 2012, p.103). Suisheng Zhao exposes a similarly negative perspective regarding the non-conflictual prospects for future Chinese energy acquisition, by emphasizing that the country faces strong attempts by established powers to block its further access to energy resources (ZHAO 2013, pp.109-110). Hence, it becomes important to evaluate whether the present demand imperatives posed by the dramatically increasing Chinese energy consumption are in effect possible to reconcile with the stated goal of cooperative mutually beneficial interactions, within both the general Chinese foreign policy strategy, and within its energy policies.

Other central elements within Chinas foreign policy agenda, which in some measure also are related to the country's overseas energy acquisition have to do with the principle of non-intervention in internal political affairs, and its goal of a non-hegemonic world order. The principle of non-intervention is clearly expressed within a Chinese whitepaper on Africa, wherein it is mentioned that China will seek to pursue developmental goals in cooperation with African countries, 'without setting any political conditions' (CHINA GOV. 2010). Zhu Liqun defends this principle by making the argument that the idea of non-interference is a 
natural product of a colonial history, which China and African countries share, also meaning that it thereby expresses a mutually shared perception, and thus cannot be perceived as unilaterally imposed by China (LIQUN 2010, p.43). In effect, the anti-interventionist policy does clear some ground for energy related cooperation with authoritarian or repressive regimes, which western companies, at least in principle, should be more constrained from doing business with. The anti-hegemonism has paralleled the policies of modernization and international opening, since these were established by Deng Xiaoping (HAMRIN 1998, p.75). The de-hegemonization of international affairs is an integral part of the notion of a harmonious world, and is thereby both a prescriptive goal within Chinese foreign policy, but also a descriptive concept referring to the perception of a more multi-polar world order in the 21st century (LIQUN 2010, p.27).

The principle of non-intervention as well as the idea of de-hegemonization imply an ideational framework with a certain co-optive potential, which at least should be considered with regards to the specific national context, within which they are interpreted. Though the universalist appeal and emancipatory nature of these foreign policy doctrines can be questioned, they nonetheless may contain a certain degree of attraction, not only for ruling elites, but more importantly, a broader popular appeal, strongly related to colonialist experience and third world oriented ideology. As it is stressed by Xiaoyu, it becomes important to consider the role of non-western nations in shaping international norms, rather than an a-priori acceptance of the general validity of norms founded upon an occidental worldview (XIAOYU 2012, p.347). The norms of non-intervention and de-hegemonization are also of a clearly intangible nature, and it is therefore presumed that they may imply a certain potential as a soft-power resource. Their effectiveness is subsequently to be evaluated in the specific country cases with regards to their possible influence on Chinas energy strategy.

\section{CHINESE ENGAGEMENT I KAZAKHSTAN}

China first became a net-importer of oil and gas in 1993 (JIAN 2011, p.3), which roughly coincided with the disintegration of the USSR and thereby also the independence of the former Soviet republics in Central Asia. Since then, China has been expanding its ties with these areas on basis of the intrinsically intertwined twin objectives of assuring stability in its western border regions and obtaining energy supplies (SUTTER 2012, p.242). The Sino-Kazakh relationship therefore implies a range of different and interrelated high-priority foreign policy concerns, spanning over both energy and security related issues, (ECONOMY 
\& MICHAEL 2014, p.150) and cannot be understood from the assumption that only the resource security vector lies at the heart of the dynamics of interactions. The energy and security related Chinese interests in Kazakhstan have nevertheless been sought enforced mutually, and the substantial investments in oil and gas pipelines in order to connect Kazakhstan to Chinas western Xinjiang province, also contain an element of consolidation of control in the border region (DANREUTER 2011, p.1356-1357). In 2006 China and Kazakhstan also held a joint military exercise, on behalf of Chinese initiative (LI \& WANG 2009, p.11). Regardless of its essentially security related constitution, the Shanghai Cooperation Organization (SCO) has also become a very important institutional vehicle for treating energy related questions (LIAO 2006, p.67). As the SCO is based upon comprehensive corporative security and mutual enforcement of confidence building measures (SHAMBAUGH 2013, p.25) it also stimulates a series of integrative dynamics which are likely to spill over into the energy related field. Economy and Michael also point to the reciprocal relationship of complementary interests pertaining to the realms of energy politics in the Central Asian theatre in effect have come to push regional politics in a more cooperative direction (ECONOMY \& MICHAEL 2014, p.163).

As roughly $80 \%$ of Chinas oil imports pass through the Malacca Strait (SHAOFENG 2010, p.2), the Central Asian oil deposits offer a very attractive opportunity for diversification of imports (PETERSEN \& BARYSCH 2011; 2013, p.40). Facing a steadily rising import demand since the early 90's, Chinese SOEs embarked on a series of acquisitions within the newly opened Kazakh oil sector, with a strong financial and diplomatic backing from the Chinese state. In 1996, the China National Petroleum Corporation (CNPC) obtained a 60.3\% stake in Aktobe Munai Gaz from the Kazakh government, as this had opened up for prospective bidding by foreign companies. In the process, CNPC managed to outbid both the US oil companies of Texaco and Amoco and the Russian Yujnimost. This success has been ascribed to CNPC's promise to build a US $\$ 3.5$ billion 3.000 kilometer pipeline, crosscutting Kazakhstan and ending in China (MCCARTHY 2013, p.272). In total, the deal amounted to a US $\$ 9.5$ billion investment, and in spite of delays with the construction of the pipeline, it was finally completed in 2006 (SUTTER 2012, p.242243).

Another important step for CNPC in Kazakhstan, was the takeover of PetroKazakhstan in 2005, which granted the Chinese SOE exclusive ownership of the Kumkol South field and a shard exploitation of the Kumkol North field, together with the 
Russian Lukoil (LIAO 2006, p.66). Preceding high-level negotiations between the Chinese and Kazakh leadership, - supposedly including the personal involvement of Hu Jintao - are said to have been a decisive factor in cementing the acquisition of PetroKazakhstan, totaling a sum of US $\$ 4.18$ billion (MCCARTHY 2013, p.276). The purchase was accompanied by a straightening of Sino-Kazakh relations the same year with the signing of the 'strategic partnership' agreement, which also to some extend can be seen as a counter measure to a markedly increased US presence in the region in the post 9/11 period. Chinese foreign policy analyst Xuanli Liao draws a clear connection between the establishment of this strategic partnership and the successful acquisition of PetroKazakhstan, in face of competition from both the Indian Oil \& Natural Gas Corp. and Lukoil. (LIAO 2006, pp.66-67)

The situation with Chinese public institutions as financiers in various respects has thus become a defining trait in Chinas engagement in order to procure access to Kazakh crude reserves. In recent years, this tendency has been exacerbated by political involvement. The Chinese leadership spurred the China Exim Bank to provide a US $\$ 5$ billion loan to the Kazakhstan Development Bank for infrastructure projects and CNPS has also directly funded the domestic Beineu-Bozoi-Akbulak gas pipeline in southern Kazakhstan. Such loans have been concessional of CNPC's increased - and in many cases preferential - access to hydrocarbon resources, as well as the possibility to buy an equity stake in MangistaMunaiGaZ in 2009 (MCCARTHY 2013, p.277). The marked governmental involvement in securing especially CNPCs access to Kazakh energy reserves has significantly contributed to Kazakhstan becoming the country with the highest Chinese oil industry equity share in the world, reaching $23 \%$ in 2010. In spite of this, not all of CNPCs equity oil is shipped back to China through the newly constructed pipelines, but is rather sold on the world market, depending on the particular price conditions and possibilities for profit maximization which the Chinese SOE faces at a given time. (JIANG \& SINTON 2011, p.18) Along with these measures, China has sought to strengthen its ties with Kazakhstan through the establishment of transportation and other economic links (IBRAIMOV 2009, p.51). Joseph McCarthy also emphasizes that the close political involvement by the Chinese leadership in guaranteeing CNPCs operational environment in Kazakhstan, must be seen as a consequence of an increasingly reassertive Kazakh leadership, seeking to maximize gains from foreign oil companies operations in the country, and in some cases also threatening international oil companies (IOCs) with renationalization (MCCARTHY 2013, p.271-272). The same decisive impact of the policy support is stressed by Xuanli Liao, who hints that such politically created 
privilege helps to compensate Chinese companies for a more modest financial stance, than that enjoyed by many large IOCs (LIAO 2006, p.68).

\section{POST-CONFLICT ANGOLA AND THE CHINESE ENTRANCE}

Diplomatic ties between China and Angola span back to 1983, although a deeper relationship was only forged by the internationalization of the Chinese economy, which led the country to amplify its global search for natural resources (ALVES 2013, p.107). The cessation of internal hostilities in 2003 provided the foundation for the establishment of constitutional order, which also led to more stable conditions for investments and financing for the development of the Angolan oil industry (BURGOS \& EAR 2012, p.355). The Chinese and Angolan developmental goals were of an apparently complementary nature, with China possessing ample financial resources and facing a steadily growing demand for oil, whereas Angola was in need of obtaining the necessary capital to develop its abundant hydrocarbon resources (ALVES 2010, p.6). In this situation, China particularly assumed the role of a long-term financer, (BURGOS \& EAR 2012, p.358) with the China Export-Import Bank (Exim Bank) occupying a central role, by extending a total of more than US\$10 billion in oil-backed credit lines to the Angolan government from 2004-2010 (CORKIN 2011, p.1).

In 2002, the Exim Bank and China Construction Bank funded the electrical grid projects in major Angolan cities as well as the initial stage of Luanda's railway rehabilitation (ALVES 2010, p.11). The establishment of concessional loans destined to finance infrastructure projects and other mayor public works, has also been a significant element within the Sino-Angolan relationship during the first decade of the new millennium. The first of such credit lines was extended to Angola by the Exim Bank in 2004, and the US $\$ 2$ billion loan was dependent upon the purchase of at least $70 \%$ of construction materiel, equipment and labor services from China (ALVES 2013, p.108). The extension of the first credit line from Exim Bank coincided with the China Petroleum and Chemical Corporation's (Sinopec) first acquisition within Angola, in the form of a 50\% stake in the oilfield block 18, for the alleged sum of US $\$ 25$ million (CORKIN 2011, p.2). Block 18, was to be sold by Shell to Indian Oil \& Gas National Company (ONGC) yet, the Angolan SOE, Sonangol, used its preemptive right to make sure that Sinopec was given first priority. Hence, Sinopec Overseas Oil \& Gas was established as a joint venture between the Chinese and Angolan SOEs in September 2004 (ALVES 2013, p.108). 
In the course of the past decade, two further credit lines financing projects of the Angolan governments Infrastructures Program were extended by the Exim Bank in 2007 (ALVES 2010, p.11) and a third in 2009 (Ibid, 13). The loans have been paralleled by a rapid rise in the total value of Chinese crude imports from Angola, up from US $\$ 1$ billion in 2002 to US $\$ 33,3$ billion in 2012 (ITC, 2014). Consequentially, since 2007, China has been the main destination for Angolan crude exports, accounting for some 43\% in 2010 (ALVES 2013, p.107). Angola has thus become a central oil supplier for China, and has on two occasions, in early 2006 and in the beginning of 2008, overtaken Saudi Arabia as the main source of Chinese crude imports (Ibid 2010, pp.8-9). In 2006, China became Angola's largest trading partner; a position which it has come to occupy evermore markedly since then (ITC, 2014).

The relationship between financial and infrastructure provision on one hand, and increased access to hydrocarbon resources on the other, has not only been evident in cases when interests between China and Angola have coincided, but also in cases when the absence of the former appears to have negatively affected the later. This became evident in the case of the Lobito refinery, which was to be constructed as a US $\$ 3.5$ billion joint venture between Sinopec and Sonangol. The deal was signed in 2005 upon the concession of rights to develop the oil fields of block 15/06, 17/06 and 18/06, to Sinopec (ALVES 2010, p.19). Yet, the joint project encountered a significant obstacle related to disagreements between Sinopec and Sonangol, about which markets the refinery would supply; whereas Sinopec wanted production to fit technical requirements for supplying Asian markets, Sonangol intended to supply domestic markets and sell excess capacity to Europe. The divergences between the two SOEs eventually resulted in Sonangol going forward with the project alone, and the Angolan government auctioning the blocks which Sinopec initially had gained the right to develop (Ibid p.19).

The deep economic engagement by China has had a broad range of ramifications within Angolan society. Whilst some measures might have been related to the initial object of securing access for Chinese companies to the country's crude reserves, they may also, depending on how they are perceived by different sectors within the population, produce either negative or positive feedbacks, which will determine the possibilities for further Chinese involvement. The Exim credit lines, which have constituted the backbone of Chinese strategy to facilitate access Angolan crude reserves, have been materialized as a range of oil-backed credits within health, education, energy, agriculture and telecommunications (CAMPOS \& VINES 2008, p. 8). Educational cooperation between the two countries has also made it possible for Angolan students and specialists to be trained in China (BURGOS 
\& EAR 2010, pp.358-359). Angola observer Ana Christina Alves, notes that the maintenance of a healthy relationship to the Angolan leadership has been an essential part of the deep Chinese engagement within the country (ALVES 2010, p.24) but also that the financing of infrastructure and influx of cheap Chinese consumer goods has been well regarded in the population at large (Ibid, p.15). On the other hand, the alleged willingness to use bribery as a means to obtain contracts and the high degree of absence of political and governance related conditions attached, has also been criticized by oppositional forces within Angola, claiming that these practices undermine efforts to improve public accountability and good administration. Likewise, parts of the Angolan private sector have also criticized Chinese enterprises operating in Angola for relying excessively upon imported Chinese workforce and of underbidding local competitors. (SUTTER 2012, p.312; BURGOS \& EAR 2012, p.358) The use of imported labor has not only been the case within civil construction projects, but has also been clearly evident within the oil sector, where cases have shown that Chinese enterprises hire significantly less Angolans when compared to Western companies (HORTA 2009). The need for reconstruction, high degree of financing and low competition has made Angola a particularly lucrative market for Chinese enterprises and construction business (CAMPOS \& VINES 2008, p.19).

The close entanglement of access to natural resources conditioned upon infrastructure provision, which in turn is provided by Chinese contractors, has also often been referred to as the "Angola model". The lack of further political conditions, raises the question of whether the "Angola model", which clearly reflects the Chinese embracement of the principle of non-intervention, should be seen as an opportunistic short term strategy, or rather as a cornerstone in long term Chinese foreign engagement.

\section{CHINA IN VENEZUELA; PRAGMATISM ABOVE ALL}

With an abundance of hydrocarbon resources, Latin America has gained a central role within the Chinese strategy to ensure energy diversification at the outset of the 21st century (BECARD 2013, p.229) which has led to a notable intensification of relations with governments within the region (KOTSCHWR et al 2012, p.2). Venezuela has become of particular interest to the Chinese, as a consequence of its enormous reserves of heavy bitumen crude, which according the US Geological Survey may amount to some 513 billion barrels of recoverable oil (USGS 2009). From diplomatic ties were established between The Peoples Republic of China and Venezuela in 1974 and until 1999, the Sino-Venezuelan 
relationship was characterized by sporadic high-level contact and modest economic interaction (HONGBO 2014, p.650). Chinese oil companies have been operating in Venezuela since 1997, when they gained access to the Caracoles and Intercampo oilfields in the Maracaibo region (ELLIS 2010, p.3) but relations were significantly intensified by the election of Hugo Chavez Frías in 1999 (HONGBO 2014, p.651).

On Hugo Chavez first visit to China as newly elected in 1999, Memoranda of Understanding were signed on mutual investment protection agreements, the establishment of a Mixed Joint Energy Committee and finally regarding a credit loan to Venezuela provided by the Bank of China. A few years later in 2001, a strategic partnership of common development was signed between the two countries, along with the creation of a SinoVenezuelan commission for high-level exchange (NOESSELT and SOLIZ-LANDIVAR 2013, p.4). The same year, China and Venezuela also agreed upon a bilateral Strategic Energy Plan, intended to extend until 2011, implying a planned increase in Venezuelan oil exports to China and a substantial Chinese financing of Venezuelan railway construction (CHENG \& SHI 2008, p.123). Over the following years, the cooperation between the two nations came to approximate an institutionalized model founded upon the oil sector, with Chinese credits financing infrastructure, social services, technology, mining and agricultural development, conditioned upon the repayment of Venezuelan crude exports to China (DOWNS 2011, p.51). Joint measures have also extended to the provision of oil rigs by Chinese enterprises, construction of oil tankers as well as the establishment of a US\$6 billion refinery for processing the Venezuelan bitumen crude in the Chinese Guangdong province (ELLIS 2010, p.9). The Sino-Venezuelan cooperation is thus a result of the high degree of economic complementarity, and fundamentally driven by market forces, yet, molded by the strong direct involvement of both governments (HONGBO 2014, p.654).

A paramount pillar within the energy related cooperation has nevertheless been the creation of a financing mechanism in form of the China-Venezuelan Joint Fund in 2007, by the China Development Bank, CNPC and the Venezuelan Bank for Economic and Social Development - or BANDES. (DOWNS 2011, p.49). The fund has functioned as the main vehicle for the concession of three grand loans: of US $\$ 6$ billion in 2007 , US $\$ 20$ billion in April 2010 and US $\$ 12$ billion in June the same year, all to be repaid over a 10 year period (ELLIS 2010, p.3). The extension of the large loans in 2010, coincided with the China National Offshore Development Company (CNODC) obtaining the right to develop the Junin-4 block in the Orinoco field, through a joint venture with PDVSA. The same year CNPC also accounted for operations of 15 mature fields in the Anzoátegui province (Ibid, 
p.8). In 2012 , a second agreement for a US $\$ 12$ billion Joint Fund was made, with the China Development Bank and Venezuela's National Development fund contributing with the financing, which was to take place in a dual stage of implementation (HONGBO 2014, p.655). The agreement implied a series of investments in a broad spectrum of the Venezuelan economy, spanning from the electricity grid, construction of thermo generation plants, a hydro-electrical plant, railways, agricultural development, telecommunications as well as the obligation to further invest in the Orinoco region (SAMPER 2012, p.8). Yet, with financial problems and an oil production stagnated around 2,5 million barrels pr. day, Venezuela has been in need of credit, which led to a third US\$18 billion financing agreement with China in 2013. The arrangement was conditional upon implementation in three stages, and meant that debt repayment in form of crude would amount to some 230.000 barrels pr. day (HONGBO 2014, p.655). The Sino-Venezuelan relationship has thereby come to assume noticeable asymmetrical features during recent years, with the large loans being repaid with increasing crude exports to China, roughly reaching 500,000 barrels pr. day in 2014, of which nearly half went to the repayment of prior debt obligations (CUNNIGHAM 2014).

Recent relations between China and Venezuela have also extended beyond the energy sector and implied a range of issues indirectly concerned with this. During recent years, Venezuela has purchased fighter jets and air defense systems and also acquired important military technology (ELLIS 2010, p.5). Apart from the military domain, exchanges have also taken place in cultural, educational and scientific fields (HONGBO 2014, p.651). An essential point, which inevitably has smoothened general cooperation between China and Venezuela, has been the latter's firm support for the One-China policy. Of the modest sized group of states which fully recognize Taiwan the day today, 11 are to be found within the Central American and Caribbean Region. Though presently an informal understanding exists between China and Taiwan, regarding not to seek to actively push any nation to switch recognition, the issue continues to be of high importance to both countries. In this respect, Venezuela is in a key position for China, as the South American country exports subsidized oil within the Petrocaribe scheme, which benefits many of the countries recognizing Taiwan within the region, and thereby also constitutes a significant economic leverage for Caracas (ELLIS 2010, p.7).

On the geostrategic level, Venezuela's challenge to US hegemony within the region may also coincide with the general Chinese interests within the region, and thereby stimulates a certain Sino-Venezuelan alignment. This loosely shared worldview nevertheless covers over 
significant differences when translated into specific objectives by each country. An essential goal for China within Latin America is access to the region's natural resources, but within this search, China has strictly avoided the costs of challenging the US within the region (SUTTER 2012, p.314). The opposition to the FTAA as well as the aversion towards neoliberal capitalism, has undeniably created space for China and its enterprises to get a stronger foothold within the region (ELLIS 2010, p.6). The assenting political orientation of Caracas has similarly led to a relatively privileged positioning within the Venezuelan market for Chinese companies (Ibid, 4). Nonetheless, the sheer size of the US market and the vital importance of the Chinese trade surplus with it, has meant that China has been very careful not to take any steps which might lead to a more protectionist United States (DANREUTER 2011, p.1350). Hence, the Venezuelan hopes that China might move in the direction of a strategic alliance, have thus been kept at an arm's length by China. Good working relations with the US have thereby come to outweigh the strategic partnership with Venezuela (CHENG \& SHI 2008, p.140).

\section{CONCLUDING REMARKS UPON THE NATURE OF POWER AND CHINESE OIL ACQUISITIONS}

As the analysis of the country cases indicates, the Chinese aspirations to access oil deposits have been strongly supported by infrastructure provision, construction projects and financial credits issued below special terms. These measures approximate what Chen \& Chang (2013) conceptualize as the application of material resources for the goal of 'attraction', be it economic aid, or military, civil, or industry cooperation; or rather, soft hardpower. In this respect the Chinese oil companies do appear to have been adhering to a market oriented logic of seeking profitable investment. The unorthodox features of their strategy have rather been related to the strong support from Chinese public institutions in order to facilitate their access and operational environment, primarily through significant material inducements to oil rich countries. What also stands clear from the cases reviewed, is that the main power resources applied by China in relation to the obtainment of energy, have been of a markedly tangible character. Whether this has to do with the very nature of policies related to the energy sector stands as an open question. However, some measures which have do to with a more immaterial, "soft", as well as intangible power-resource domain, are worth keeping in mind. These could be mentioned as the Chinese educational cooperation with both Angola and Venezuela, as well as the institutionalization promoting a constructive 
approach to common challenges, which the energy cooperation with Kazakhstan has stimulated.

In the case of Venezuela, a certain degree of apparent ideological alignment and shared worldview, seems to have facilitated cooperation within the energy sector. The shared anti-hegemonic ideals and "Global South" political identity are worth mentioning as a ideational soft-power resources, which are likely to have facilitated energy cooperation. In the China-Venezuelan case, though, it is important to keep an eye on the contextual nature which has allowed this normative power capability to become evident: the political identity of the Venezuelan governments since 1999 and its opposition to the elements of the international system with roots in a occidental neo-liberal order. This has resulted in a high measure of proneness to Chinese engagement within the country, and Caracas in many respects appears to have been the active part, in trying to forge an ideological dimension to the economic complementarities between the two nations. In the Chinese strategy for international insertion, the foreign policy principles of keeping a low profile and of deideologization of the country's foreign policy, seem to have overshadowed any possible interests in challenging US hegemony.

The indications that the Chinese projection of soft-hard power in Angola has produced a positive attitude towards China within some segments of society, also blurs the picture of what at first appears to be a very materialist Chinese energy strategy: soft-hard power application producing soft-soft power. Importantly, this raises the question of power dynamics as a reciprocal force, initially exercised by one party, but in the process of being absorbed by the other, transforming into another power domain and opening new channels for the projection of different power resources. This also paves the way for a more constructivist focus upon the culture which characterizes the interactions in a particular temporal and spatial context, rather than trying to deduce specific power resource variables which supposedly would shape the outcome of interactions. Furthermore, it raises the question of whether it is indeed possible to meaningfully try to separate the hard and soft nature of power, and whether the essential objective should not rather be to evaluate the conjunction of different channels activated in the attempts of power projection, some pertaining to the soft, others to the hard realm.

Joseph Nye (2011) does treat the complexities of the interconnection between hard and soft power through the notion of 'smart power', within the strategies of both small and large states, and also proves that these historically tend to be complementary forces. Though 
the cases examined within this paper indicate the presence of some modest soft-power projection, they generally conclude that the Chinese strategy in relation to oil rich countries, relies heavily on materialist inducement in the form of tangible power resources. In this regard, the development over time is an aspect which has been difficult to examine, because of the relatively recentness of the strong Chinese engagement in obtaining natural resources abroad. This poses two relevant questions: the first relates to whether economic interactions actually provide an initial and necessary basis, upon which an institutionalized cooperation and, eventually, channels for ideational and cultural interactions and influence subsequently will emerge? The second question relates to whether the imbalances inherent in the economic asymmetries and diverging strategic exceptions, in the case of Venezuela, or the tensions which the strong sudden presence of China in Angola has provoked in some parts of society, are indeed rendering a pragmatically materialist focused power projection strategy as an attractive option in the long run? This issue leads attention towards complexities inherent in the process of power exercise, which lie at the hearth of Nye's notion of smart power. In line with this approach, the first question to ask would be related to Chinas preferred outcome from its interactions with oil providers, while other central queries would be concerned with context, the preferences of partners and the probabilities of success. From the previous analysis it stands clear that the application of available power recourses, in the existing context, has been successful in providing energy recourses in the intermediate term. Yet, whether the complicated principle of non-intervention or the often diffuse "southern common identity" is indeed a stable basis for China's relations with its offshore providers, stands as a very open question. If China seeks to make these initial commercial contacts constitute the foundation for deeper future cooperation, it might find it necessary to consider its own interests more closely together with those of its partners. As the Chinese foreign oil dependence does not appear to be diminishing within any near future, the feedback from the initial experiences of acquiring this resource abroad, should imply valuable knowledge for defining a more sustainable long-term relationship with overseas providers.

\section{BIBLIOGRAPHY}

ALVES, A. C. (2013) Chinese Economic Statecraft: A Comparative Study of China's Oilbacked Loans in Angola and Brazil. Journal of Current Chinese Affairs 1/pp. 99-130.

ALVES, A. C. (2010) The Oil Factor in Sino- Angolan Relations at the Start of the 21 st Century. Occasional paper no. 55. South African Institute of International Affairs, pp.1-25. [Available from: http://www.saiia.org.za/occasional-papers/the-oil-factor-in- 
sino $\% \mathrm{E} 2 \% 80 \% 93$ angolan-relations-at-the-start-of-the-21st-century] [Accessed: 02/11 2014].

BECARD, D. R. (2013) China Diplomacy and Trade in Latin America. Estudos Internacionais v. 1 n. 2 jul-dez. p. 223-239.

BURGOS, S.; EAR, S. (2012) China's Oil Hunger in Angola: history and perspective, Journal of Contemporary China, 21(74), pp. 351-367.

CAMPOS, I.; VINES, A. (2008) Angola and China: A Pragmatic Partnership. Working Paper Presented at a CSIS Conference, "Prospects for Improving U.S.-China-Africa Cooperation". [Available from: http://csis.org/files/media/csis/pubs/080306_angolachina.pdf] [Accessed: 08/11 2014].

CHENG, Z.; CHANG, L. (2013) The Power Strategy of Chinese Foreign Policy; bringing Theoretical and Comparative Studies Together. NFG working paper no.03.

[Available

from: https://www.asianperceptions.eu/system/files/private/NFG_Working_Paper_03_2013_6. pdf] [Accessed: 05/9 2014].

CHENG, J., Y. S.; SHI, H. (2008) Sino-Venezuelan Relations: Beyond Oil. Issues and Studies 44, no.3, pp. 99-147.

CHINA GOV. (2007) Whitepaper; China's Energy Conditions and Policies. Information Office of the State Council of the People's Republic of China. [Available from:

http://www.china.org.cn/english/whitepaper/energy/237089.htm] [Accessed: 25/10 2014].

CHINA GOV. (2013) Whitepaper; China-Africa Economic and Trade Cooperation. Information Office of the State Council of the People's Republic of China. Available from: [http://www.china.org.cn/government/whitepaper/node_7107834.htm] [Accessed: Nov 3, 2014].

CORKIN, L. (2011) China and Angola Strategic partnership or marriage of convenience? Angola Brief, volume 1, no.1. pp.1-4. January 2011.

CUNNIGHAM, N. (2014) Increasingly desperate Venezuela makes Oil-For-Cash Deal with China. oilprice.com, July 28th, 2014. [Available from: http://www.economonitor.com/blog/2014/07/increasingly-desperate-venezuela-makesoil-for-cash-deal-with-china/] [Accessed: 15/11 2014].

DANNREUTHER, R. (2011) China and global oil: vulnerability and opportunity. International Affairs 87:6 pp. 1345-1364.

DOWNS, ERICA (2011) Inside China, Inc: China Development Bank's Cross-Border Energy Deals. John L. Thornton China Center Monograph Series. Brookings Institute. [Available from: http://www.brookings.edu/ /media/research/files/papers/2011/3/21\%20china $\% 20$ ener gy\%20downs/0321_china_energy_downs.pdf]. [Accessed: 31/1 2015]. 
ECONOMY, E.; LEVY, M. (2014) By all Means Necessary: How China's Resource Quest is changing the World. Oxford: Oxford University Press.

ELLIS, E., R. (2010) "Venezuela's Relationship with China: Implications for the Chávez Regime and the Region". University of Miami, Centre for Hemispheric policy Challenges to Security in the Hemisphere Task Force. [Available from: https://umshare.miami.edu/web/wda/hemisphericpolicy/Ellis_Venezuelas_Relationship_ w_China.pdf] [Accessed: 15/11 2014].

HAMRIN, C. L. (1998) Elite Politics and Foreign Relations. In Robinson; Thomas \& Shambaugh, David (editors) Chinese Foreign Policy: Theory and Practice. Oxford: Clarendon Press.

HONGBO, S. (2014) China-Venezuelan Oil Cooperation Model. Perspectives on Global Development and Technology vol.13, pp. 648-669.

HORTA, L. (2009) China in Africa: Soft Power, Hard Results. YaleGlobal, 13 November 2009, [Available from: http://yaleglobal.yale.edu/content/china $\% \mathrm{E} 2 \% 80 \% 99$ s-soft-powerafrica-could-have-hard-results]

[Accessed: 08/11 2014].

IBRAIMOV, S. (2009) China-Central Asia Trade Relations: Economic and Social Patterns. China and Eurasia Forum Quarterly, Volume 7, No. 1 (2009) p. 47-59.

ITC - International Trade Centre (2014) Trade map - International Trade Statistics, [Available from: http://www.trademap.org/tradestat/Country_SelProduct_TS.aspx] [Accessed: 14/11 2014].

JIAN, Z. (2011) China's energy security: Prospects, Challenges, and Opportunities, Brookings Institute, Center for Northeast Asian Policy Studies, CNAPS Visiting Fellow Working Paper. [Available from: http://www.brookings.edu/ / media/research/files/papers/2011/7/china $\% 20$ energy $\% 20$ zhang/07_china_energy_zhang_paper.pdf] [Accessed: 02/02 2015].

JIANG, J.; SINTON, J. (2011) Overseas investments by Chinese National oil Companies: Assessing the drivers and impacts. International Energy Agency, Information Paper. [Available from: http://www.iea.org/publications/freepublications/publication/overseas_china.pdf] [Accessed: 03/11 2014].

KOTSCHWAR, B.; MORAN, T. H; MUIR, J. (2012) Chinese Investment in Latin American Resources: The Good, the Bad, and the Ugly. Peterson Institute for International Economics. Working paper series. [Available from: http://www.iie.com/publications/wp/wp12-3.pdf] [Accessed: 10/12 2014].

LAMPTON, D. (2001) The making of Chinese Foreign and Security Policy: in the Era of Reform (1978-2000). Stanford: Stanford University Press.

LI, H.Y.; ZHENGZU, W. (2009) Assessing China's Influence in Asia: a Dominant Regional Power? Briefing Series, The University of Nottingham, China Policy Institute. 
LIAO, X. (2006) Central Asia and Chinas Energy Security. China and Eurasia Forum Quarterly, Volume 4, No. 4. pp. 61-69.

LIQUN, Z. (2010) China's Foreign Policy Debates. Chaillot Papers, European Union Institute for Security Studies, ISSN 1017-7566. [Available from: http://www.iss.europa.eu/uploads/media/cp121-China_s_Foreign_Policy_Debates.pdf] [Accessed: 30/8 2014].

MCCARTHY J. (2013) Crude 'Oil Mercantilism'? Chinese Oil Engagement in Kazakhstan, Pacific Affairs: Volume 86, No. 2 pp. 257-280.

NOESSELT, N.; SOLIZ-LANDIVAR, A. (2013) China in Latin America: Competition in the United States' "Strategic Backyard" German Institute for Global and Area Studies. ISSN 2196-3940. [Available from: http://www.gigahamburg.de/de/system/files/publications/gf_international_1307.pdf] [Accessed: 01/02 2014].

NYE, J. S. (1990) Bound to Lead. New York: Basic Books.

NYE, J. S. (2004) Soft Power; The Means to Success in World Politics. New York: PublicAffairs.

NYE, J. S. (2011) The Future of Power. New York: PublicAffairs.

PETERSEN, A.; BARYSCH, K. (2011) Russia, China, and the Geopolitics of Energy in Central Asia. Center for European Reform. ISBN 978190761701 0. [Available from: http://www.cer.org.uk/sites/default/files/publications/attachments/pdf/2011/rp_010-

4118.pdf] [Accessed: 07/12 2014].

SAMPER, H. G. (2012) ¿Se torna Venezuela más dependiente de China? Debates IESA, volume XVII, Número 2.

SHAMBAUGH, D. (2013). China goes Global: The Partial Power. Oxford: Oxford University Press.

SHAOFENG, C. (2010) China's Self-Extrication from the "Malacca Dilemma" and Implications, International Journal of China, vol. 1, No. 1, January 2010, pp. 1-24.

SUTTER, R. (2012) Chinese Foreign Relations: Power and Policy since the Cold War. Rowman and Littlefield Publishers. Ebook. ISBN 9781442211360

USGS (2009) - UNITED STATES GEOLOGICAL SURVEY. An Estimate of Recoverable Heavy Oil Resources of the Orinoco Oil Belt, Venezuela. US Department of the Interior. World Petroleum resources project. Fact sheed 2009-3028. [Available from: http://pubs.usgs.gov/fs/2009/3028/pdf/FS09-3028.pdf] [Accessed: 30/10 2014].

WENDT, A. (1999) A Social Theory of International Politics. Cambridge: Cambridge University Press. 
XIAOYU, P. (2012) Socialisation as a Two-way Process: Emerging Powers and the Diffusion of International Norms. The Chinese Journal of International Politics, Vol. 5, 2012, 341367.

ZHAO, S. (2013) Chinese Foreign Policy as a Rising Power to find its Rightful Place. PERCEPTIONS, Spring 2013, Volume XVIII, Number 1, pp. 101-128. 